Chirurgia (2021) 116: 102-108

No. 1, January - February

Copyright@ Celsius

http://dx.doi.org/10.21614/chirurgia.116.1.102

\title{
Stapled Hemorrhoidopexy: Technique and Long Term Results
}

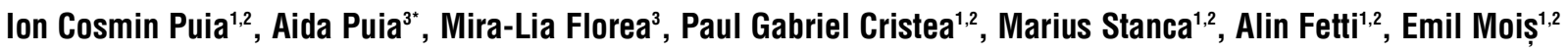 \\ ${ }^{1} 3^{\text {rd }}$ General Surgery Clinic, "Octavian Fodor" Regional Institute of Gastroenterology and Hepatology, Cluj-Napoca, Romania \\ ${ }^{2}$ General Surgery Department, "Iuliu Hatieganu" University of Medicine and Pharmacy, Cluj-Napoca, Romania \\ ${ }^{3}$ Family Medicine Department, "Iuliu Hatieganu" University of Medicine and Pharmacy, Cluj-Napoca,Romania
}

${ }^{*}$ Corresponding author:

Aida Puia MD

Str. 21 Decembrie 30, Cluj-Napoca

Romania

E-mail: draidapuia@gmail.com

\section{Rezumat}

Hemoroidopexia prin sutură mecanică: tehnică și rezultate pe termen lung

Introducere: Hemoroidopexia cu stapler circular (operația Longo) este o tehnică destul de rar aplicată în țara noastră, poate şi datorită faptului că reprezintă o abordare radical diferită de hemoroidectomie, la care se adaugă un cost crescut şi necesitatea unei instruiri specifice. Prezentăm rezultatele noastre pe termen lung cu tehnica standard.

Metodă: Datele a 35 de pacienți cu hemoroizi simptomatici de gradul II şi III la care s-a efetuat hemoroidopexia în intervalul 01 ianuarie 2012 - 04 decembrie 2020 au fost colectate retrospectiv. Sex ratio masculin: feminin a fost de 3: 4 şi vârsta medie 45 (28-60) de ani. La controalele postoperatorii s-a efectuat de regulă tuşeul rectal şi s-a evaluat recidiva hemoroidală sau prolapsul.

Rezultate: Timpul operator mediu a fost de 42 (30-70) $\mathrm{min}$. Necesarul de analgezice administrate parenteral în primele 24 de ore au fost în medie de 1,52 doze. Spitalizarea medie postoperatorie a fost de 1,55 (1-2) zile. Un singur pacient a avut nevoie de reintervenție pentru o hemoragie pe linia de staplare, doi pacienți au avut o tromboză a unui pachet hemoroidal intern şi la un pacient $\mathrm{s}$-a diagnosticat un prolaps la controlul efectuat la 3 luni. $\mathrm{Nu}$ s-a înregistrat nici un hematom, stenoză anastomotică, durere anală persistentă sau incontinență anală. Un pacient a menționat un disconfort legat de prezența agrafelor de sutură. Pacienții au fost urmăriți timp de 6 (1-9) ani. Rata de satisfacție a fost de $94 \%$. Concluzii: Hemoroidopexia cu stapler circular este o metodă sigură, puțin dureroasă şi cu o durată redusă de internare post- 
operatorie. O selecție riguroasă a cazurilor şi aplicarea unei tehnici chirurgicale corecte permit obținerea unor rezultate bune pe termen lung şi oferă un grad de satisfacție ridicat pacienților.

Cuvinte cheie: hemoroizi, hemoroidopexia cu stapler circular, PPH, tehnica Longo

\section{Abstract}

Background: Stapled hemorrhoidopexy (Longo operation) is a infrequent technique in our area. A different concept from hemorrhoidectomy, a proportionally important raise in cost and a special training may have contributed to it. We report our long-term results with the standard technique.

Methods: The data of 35 patients with symptomatic second- and third-degree hemorrhoids who had stapled hemorrhoidopexy using a PPH03 stapler, from 01 January 2012 to 04 December 2020, were retrospectively collected. The sex ratio male: female was 3:4 and the mean age 45 (range 28-60) years. The follow-up consisted in a rectal exam and evaluated anatomical recurrence or prolapse.

Results: The mean operative time was 42 (30-70) min. The mean parenteral analgesic doses during the first $24 \mathrm{~h}$ were 1,52 . The mean postoperative hospital stay was 1.55 (1-2) days. A single patient needed reoperation for a staple line bleeding, two patients had a thrombosis of internal hemorrhoids and in one patient a small prolapse was diagnosed at 3 months follow-up. No hematoma, anastomotic stenosis, persistent anal pain, tenesmus, or impaired anal continence was recorded. One patient mentioned discomfort related to the presence of staples. Patients were followed-up for 6 (1-9) years. Global satisfaction rate was $94 \%$.

Conclusion: Stapled hemorrhoidopexy procedure is a safe and feasible procedure, which necessitates few analgesics and allows an early discharge. A rigorous selection of cases and a correct surgical technique allow to obtain good long-term results and offer a high level of patients satisfaction.

Key words: hemorrhoids, stapled hemorrhoidopexy, PPH, Longo procedure

\section{Introduction}

The management of hemorrhoids comprises conservative procedures and surgery. Apart from excisional hemorrhoidectomy, less aggressive surgical procedures like transanal hemorrhoidal dearterialization and stapled hemorrhoidopexy were developed.

The use of staples for the treatment of hemorrhoids started with linear devices. Antonio Longo adapted the circular stapler and developed a complete set of instruments. He called the approach "Procedure for Prolapse and Hemorrhoids". Along with the acronym PPH, the technique is also known as stapled hemorrhoidopexy or Longo-operation.
It gained wide acceptation in the late '90 and is now applied worldwide (1).

Initial skepticism related to the presence of staples was followed by data demonstrating that the $2 \mathrm{~mm}$ small titanium staples will either be buried in the mucosa or will be eliminated with faeces. Only $1 \%$ of all patients claim to be bothered by them and even fewer accept a surgical removal. An interesting issue is the risk of a penile injury by a staple during anal intercourse. A rectal exam after 6 weeks should confirm the safety of such an approach.

Serious complications such as rectal perforation, full thickness resection, stenosis, staple line failure or bleeding are very rare (2). A partial stapled hemorrhoidopexy, recently 
developed, seems to bring the advantages of PPH and is associated with reduced postoperative pain and urgency, better postoperative anal continence, and minimal risk of rectal stenosis (3). A hand sutured hemorrhoidopexy, advocated by some authors, is difficult to assess, as it may vary a lot on the surgeon's individual skill and expertise (4).

The PPH technique bears some advantages. The previous surgical approaches removed the hemorrhoids along with the anoderm. PPH has a physiopathological approach, removing a 3 $\mathrm{cm}$ ring of sliding tissue and suspending the hemorrhoidal veins, thus optimizing the inflow/outflow ratio. The prolapsed mucosal and submucosal layers are sutured above the dentate line. This lifting effect also ensures a normal disposition of the perianal folds and the continence for gas. By limiting its action to an area without somatic innervation postoperative pain is low.

\section{Materials and Methods}

Our series comprised 35 patients with symptomatic second - and third - degree hemorrhoids who underwent stapled hemorrhoidopexy between 01 January 2012 - 04 December 2020 in the $3^{\text {rd }}$ General Surgery Clinic of "Octavian Fodor" Regional Institute of Gastroenterology and Hepatology. Patient's demographic data, operative time, postoperative morbidity, analgesic requirements were recorded and retrieved in a retrospective study. The sex ratio male: female was 3:4 and the mean age 45 (range 28-60) years. All patients were admitted on the day of operation, usually with preoperative bowel preparation. Metronidazole and Cephalexin were given to all patients one hour prior to surgery. Pancolonoscopy was routinely performed.

The operations were performed by attending surgeons who had followed an intensive course consisting in a theoretical part and live operative demonstrations. The first two procedures of each surgeon were done under the surveillance of a visiting tutor and the next usually in a team consisting of two surgeons having followed the course. Due to the low number of cases selected for PPH every year, the operations were performed during the whole period (2012-2020) by the same attending surgeons, as a mean to accumulate expertise.

\section{Surgical Technique}

The lithotomy position is the most frequently chosen. It is more comfortable for the patient than the prone position and the intraabdominal pressure pushing on the perineum ensures a correct evaluation of the prolapse. The prone position may be considered more favorable by some surgeons because it opens wide the anal canal. General anesthesia is more suitable for the prone position and locoregional for the lithotomy. Local anesthesia is not advisable for the first procedures.

The Circular Anal Dilator (CAD33) with the obturator in place is inserted in the anus. The procedure starts with the insertion of a lubricated obturator with gentle right-left rotating movements. An anal dilation is unnecessary as it may cause a tear and hemorrhage and thus impair the view. An extra amount of lubricating jelly should be applied on the perianal skin for an easier insertion.

The four anchoring sutures for holding the CAD in place should be passed prior to its insertion. In order to ensure the best possible reduction of the prolapse the stitches have to be placed close enough to the anus.

The reduction of the prolapsed internal hemorrhoids associates the repositioning of the perianal folds. The removal of the obturator allows a check for the complete reduction through the transparent walls of the CAD. Any fold trapped between the dilator and the anorectal wall should be reduced with a pledget swab. Some dilators have an incorporated source of light.

The anoderma has to be checked prior to securing the device in place by knotting the cutaneous stay-sutures passed through the four holes in the margins of the funnel-shaped device. A correct positioning of the CAD is a condition for a successful operation (Fig. 1). Any circumstance impairing the complete 


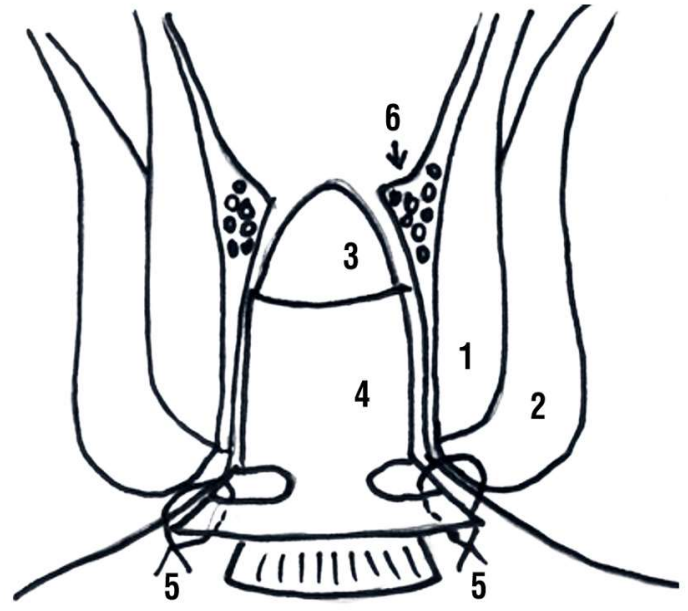

Figure 1. Circular anal dilator inserted with the obturator in place

1. Internal anal sphincter; 2. External anal sphincter; 3. Obturator;

4. Circular anal dilator; 5 . Anchoring sutures; 6 . Internal hemorrhoids

reduction contraindicates the Longo procedure, non-reducible prolapsed hemorrhoids, acute thrombosis or stenosis being the most important.

The Purse-string Suture Anoscope (PSA33) has a $90^{\circ}$ wide window allowing the placement of a purse-string suture meant to ensure the proper position of the stapled circle above the internal hemorrhoids. The window is wide enough for a fold of mucosa to protrude (Fig. 2).

In order to achieve the necessary hemorrhoidopexy, the bites have to be placed at $2 \mathrm{~cm}$ above the dentate line. Only mucosa and submucosa should be caught in the suture. The misapplication at an inadequate level or depth may result in serious complications. A full thickness bite can lead to anorectal stenosis or even recto-vaginal fistula (5). Each bite has to be made after the extraction, adequate rotation and reinsertion of the CAD. Simple intrarectal rotation bears the risk of axial torsion of the mucosa with an unequal pursestring suture.

The optimal suturing material is a 2.0 prolene monofilament set in a $25 \mathrm{~mm} \mathrm{5/8}$ atraumatic needle. The use of braided material may necessitate an excessive traction with a subsequent tear of a tissue. The suture is left

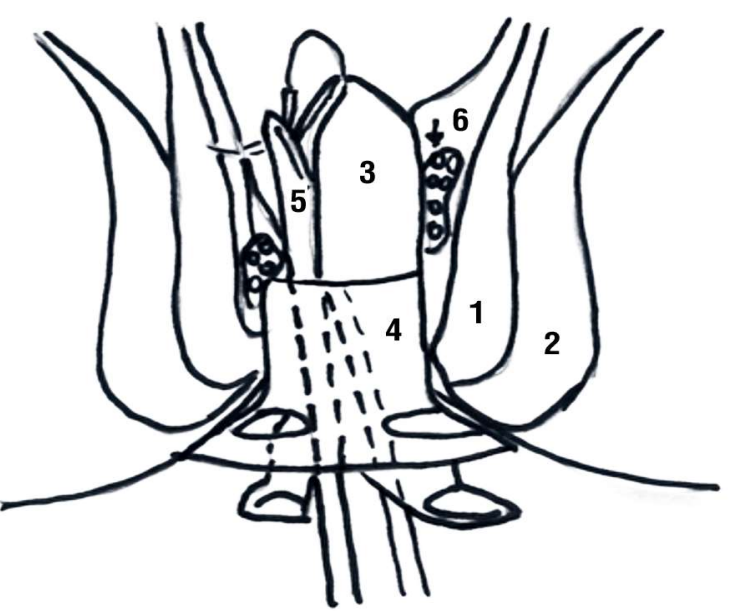

Figure 2. Anoscope allowing the placement of a purse-string suture

1. Internal anal sphincter; 2. External anal sphincter; 3. Anoscope; 4. Circular anal dilator; 5. Purse-string suture; 6 . Internal hemorrhoids

loose in order to allow the placement of the anvil.

The circular stapler has certain specific features adapted for its use in PPH. The height of the closed staples is only $0,75 \mathrm{~mm}$, thus ensuring hemostasis. The proximal end has markings for the insertion at the adequate depth. Two axial side openings called suture threadports allow the retrieval of the suture ends. Unlike usual circular devices, here the anvil is fixed thus avoiding unnecessary detachment (6). Other characteristics are common for this type of device - side safety knob, gap setting scale and closing knob.

The stapler opened at the maximum gap is inserted with the anvil beyond the pursestring. No counter-traction should be used on the suture ends to avoid tightening of the loop. In such a case the stapler has to be removed and the suture loosened. A forceful introduction may lead to one or more tearings of the wall with gap formation. The purse-string is then tightened around the trocar and tied with a simple knot. A loose loop bears the risk of being cut by the circular knife with an asymmetric resection of the fold. The ends are pulled out crossed with the ST trough the side canals.

To ensure an adequate countertraction the 


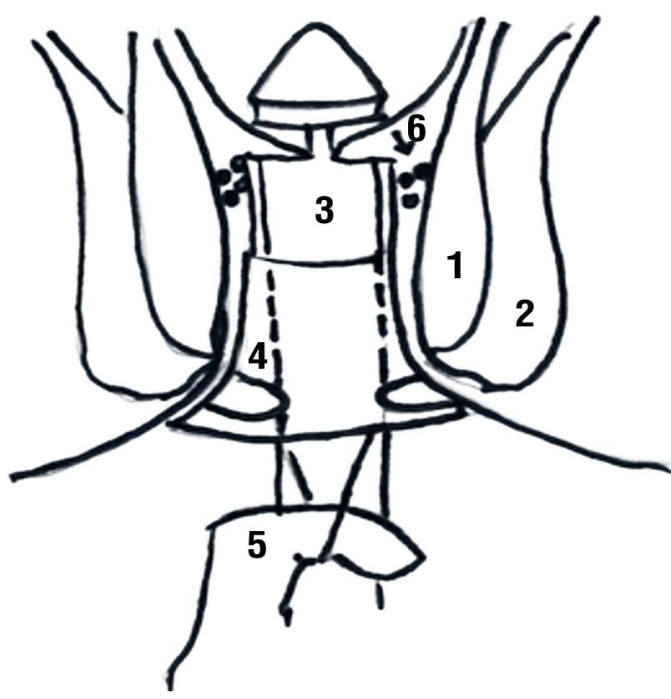

Figure 3. Opened stapler inserted with the anvil beyond the purse-string

1. Internal anal sphincter; 2. External anal sphincter; 3. Circular stapler; 4. Circular anal dilator; 5 . Finger exerting traction on suture: 6. Internal hemorrhoids

ends are held with a clamp. The stapler is partially closed by rotating the distal end knob. This allows a correct axial positioning of the device. The proximal end is pushed in position while a continuous traction on the sutures accommodates the mucosal fold between the anvil and the shaft (Fig. 3). Any additional fold caught in the instrument will be cut by the circular knife, leading to hemorrhage or fistula.

The correct depth is indicated by the $4-5 \mathrm{~cm}$ line being at the anal verge. The device is closed until the red indicator is in the green range. To allow tissue fluid to be pushed out of the suture line and ameliorate hemostasis, the stapler is fired only one minute after closure. The safety knob is released and the handle is closed with a continuous pressure. The appropriate functioning is confirmed by a specific "cracking" sound.

Unlike circular anastomosis staplers, in $\mathrm{PPH}$ the closing knob is turned anti-clockwise only $180-270^{\circ}$ in order to release the anvil. A wider opening of the gap anvil-shaft may allow the entrapment of the suture line between the anvil and the upper edge of the dilator. After freeing the tissue, the $\mathrm{CAD}$ and
PPH should be extracted simultaneously.

The stapler is opened and the resected specimen is checked. Optimally, it should have the shape of a complete ring (doughnut).

Any staple line failure has to be secured by figure-of-eight stitches with 3.0 absorbable sutures. Applying clips may lead to ischemic necrosis and secondary hemorrhage. Mono- or bipolar electrocautery is not advisable because the staples concentrate the heat thus, leading to necrotic burns around the metal. Local packing is not efficient in staple line bleeding.

An intrarectal slim gauze ribbon can be inserted above the suture line with its distal end outside the anus. Thus a bleeding will drain by capillarity along the gauze. The ribbon can be removed by gentle traction after a few hours.

Procedures for other associated anal diseases can be performed (1).

Postoperative management consists of basic nursing care, dietary modifications, sitz baths, and conventional postoperative analgesia.

The follow-up consisted in a rectal exam and evaluated anatomical recurrence or prolapse. It was routinely performed at 3 and 6 months and continued annually or whenever the patient considered it necessary. Patients were asked to assess their global satisfaction or disssatisfaction.

\section{Results}

The mean operative time was 42 (30-70) min. The mean parenteral analgesic doses during the first $24 \mathrm{~h}$ were 1,52 . The mean postoperative hospital stay was 1.55 (1-2) days. A single patient needed reoperation for a staple line bleeding. Hemostasis was achieved with absorbable sutures. Two patients had a thrombosis of internal hemorrhoids. The complication occurred on postoperative days 2-3 and was managed by conservative treatment. In one patient, who had large thirddegree hemorrhoids, a small prolapse was diagnosed at 3 months follow-up. No hematoma, anastomotic stenosis, persistent anal pain, tenesmus, or impaired anal conti- 
nence was recorded. One patient mentioned discomfort related to the presence of staples. Patients were followed-up for 6 (1-9) years. Global satisfaction rate was $94 \%$.

\section{Discussion}

The patient selection is of utmost importance achieving optimal results with this technique. $\mathrm{PPH}$ is advisable for second- and third-degree hemorrhoids and for rectal mucosal prolapse. Cases of fourth-degree hemorrhoids, especially if associated with large external components should be avoided (7). In order to achieve optimal results, patients suffering prior to the procedure from inflammatory bowel syndrome and rectal pain should receive a selective approach. Nonreducible prolapsed hemorrhoids, acute thrombosed internal hemorrhoids, anal fissures, previous prostate radiation and any cause of rectal scarring should be regarded as a relative contraindication (6).

While performing $\mathrm{PPH}$ some details have to be followed. Routine antibiotic prophylaxis should be indicated in order to prevent rare cases of severe retroperitoneal sepsis (8). A proper purse-string suture and the checking of the doughnuts are highly advisable as incomplete rings (doughnuts) of excised rectal tissue were reported by Cirocco in 2 patients who died following sepsis (9). Persistent pain and faecal urgency is cited if the muscle was found incorporated into the doughnut (10).

The optimal learning sequence comprises a course consisting in theoretical and video lectures associated with practical instrument training on simulators. Assisting experienced surgeons is followed by procedures performed under the surveillance of a tutor.

The HPP has numerous advantages, most of them statistically proved:

- less pain (no somatic innervation) $(11,12,13)$;

- short operating time: 15-30 minutes $(12,13)$;

- may be performed under local anesthesia;

- high success rate;

- blood loss comparable to conventional procedures (13);
- no risk to damage the internal sphincter;

- high patient acceptance;

- low complication rate;

- short hospital stay: 24-48 hours(12,13);

- appropriate for day surgery in selected cases (14);

- rapid return to normal activities and work 4-7 days $(12,13)$;

- no open wounds of the anoderma;

- no dressing or immediate ambulatory follow-up required;

- corpus cavernosum recti maintained;

- painless gas and stool passage;

- high patient satisfaction (12).

Some authors underline problems regarding HPP when compared to conventional haemorrhoidectomy:

- a higher rate of recurrent prolapsed $(12,15,16)$;

- less effective at reducing postoperative haemorrhage (12);

- greater difficulty in maintaining normal continence to liquid stools in the early PO days $(11,16)$;

- higher cost of single use devices.

In respect to other parameters the differences are not significant (12):

- faecal impaction needing enema;

- pain scores at 24 hours;

- short-term bleeding;

- short-term anal sepsis;

- minor bleeding at 8 weeks;

- long-term anal stricture;

- long-term anal sepsis.

Rare but serious complications were also reported:

- rectal perforation, pelvic sepsis, rectovaginal fistula, intraabdominal bleeding, and Fournier's gangrene (5);

- severe retroperitoneal sepsis (8);

- intra-abdominal hemorrhage (9).

These major complications should be "never events", avoidable by following the correct surgical technique. The most frequent mistakes are linked to the purse-string suture - bites that catch full-thickness rectal wall or even the posterior vaginal wall. A gap on the suture line caused by misfire or forceful extraction of the insufficiently opened stapler 
should be indentified at the intraoperative check and sutured, otherwise the abovementioned hemorrhagic or septic complication may occur.

We can conclude that stapled hemorrhoidopexy procedure is a safe and feasible procedure necessitating few analgesics that allows an early discharge. A specific training, a rigorous selection of cases and a correct surgical technique allow to obtain good longterm results and offer a high level of patients satisfaction.

\section{Conflicts of Interest and Source of Funding}

The authors declare no conflicts of interests. No grants or sponsorships were provided for the present research.

\section{Ethics Approval}

All procedures performed involving human participants were in accordance with the ethical standards of the 1964 Helsinki Declaration and its later amendments.

\section{References}

1. https://drantoniolongo.it/chirurgia-emorroidi/ (Internet) (cited 2020 Dec 12)

2. Ravo B, Amato A, Bianco V, Boccasanta P, Bottini C, Carriero A, et al. Complications after stapled hemorrhoidectomy: can they be prevented? Tech Coloproctol. 2002;6(2):83-8.

3. Lin HC, He QL, Shao WJ, Chen XL, Peng H, Xie SK, et al. Partia
Stapled Hemorrhoidopexy Versus Circumferential Stapled Hemorrhoidopexy for Grade III to IV Prolapsing Hemorrhoids: A Randomized, Noninferiority Trial. Dis Colon Rectum. 2019;62(2): 223-233.

4. Voiculescu S, Voiculescu EG, Scaunasu R, Balalsu C. Supradentate Transmucosal Hemorrhoidopexy (Original Technical Variant). Chirurgia (Bucharest, Romania : 1990). 2016;111(5):445-449.

5. Chen JS, You JF. Current status of surgical treatment for hemorrhoids - systematic review and meta-analysis. Chang Gung Med J. 2010;33(5):488-500.

6. Procedure for prolapse and hemorrhoids Optimal Device Performance Guide. Available from: https://www.jnjmedicaldevices.com/sites/default/files/user_uploaded_assets/pdf_assets/20 19-10/PROXIMATE-PPH-Circular-Stapler-Optimal-DevicePerformance-030063-150223.pdf (Internet) (cited 2020 Dec 12)

7. Kanellos I, Zacharakis E, Kanellos D, Pramateftakis MG, Tsachalis T, Betsis D. Long-term results after stapled haemorrhoidopexy for third-degree haemorrhoids. Tech Coloproctol 2006;10(1):47-9.

8. Molloy RG, Kingsmore D. Life threatening pelvic sepsis after stapled haemorrhoidectomy. Lancet. 2000;355(9206):810.

9. Cirocco WC. Life threatening sepsis and mortality following stapled hemorrhoidopexy. Surgery. 2008;143(6):824-9.

10. Cheetham MJ, Mortensen NJ, Nystrom PO, Kamm MA, Phillips RK. Persistent pain and faecal urgency after stapled haemorrhoidectomy. Lancet. 2000;356(9231):730-3.

11. Ganio E, Altomare DF, Milito G, Gabrielli F, Canuti S. Long-term outcome of a multicentre randomized clinical trial of stapled haemorrhoidopexy versus Milligan-Morgan haemorrhoidectomy. $\mathrm{Br} \mathrm{J}$ Surg. 2007;94(8):1033-7.

12. Reese GE, von Roon AC, Tekkis PP. Haemorrhoids. BMJ Clin Evid. 2009;2009:0415

13. Bikhchandani J, Agarwal PN, Kant R, Malik VK. Randomized controlled trial to compare the early and mid-term results of stapled versus open hemorrhoidectomy. Am J Surg. 2005;189(1):56-60.

14. Gabrielli F, Chiarelli M, Cioffi U, Guttadauro A, De Simone M, Di Mauro $P$, et al. Day surgery for mucosal-hemorrhoidal prolapse using a circular stapler and modified regional anesthesia. Dis Colon Rectum. 2001;44(6):842-4.

15. Bellio G, Pasquali A, Schiano di Visconte M. Stapled Hemorrhoidopexy: Results at 10-Year Follow-up. Dis Colon Rectum. 2018;61(4):491-498

16. Sturiale A, Fabiani B, Menconi C, Cafaro D, Fusco F, Bellio G, et al. Long-term results after stapled hemorrhoidopexy: a survey study with mean follow-up of 12 years. Tech Coloproctol. 2018;22(9): 689-696. Erratum in: Tech Coloproctol. 2018 Oct 11. 